\title{
食品添加物粒子が腸内細菌叢に与える影響
}

\author{
徳本 勇人 ${ }^{1 *}$, 野村 俊之 ${ }^{1}$, 星 英之 ${ }^{2}$, 新居 靖崇 ${ }^{1}$, 大谷 俊晴 ${ }^{1}$, 野本 健太 ${ }^{1}$
}

\section{Nano Particle as Artificial Food Additive Influence to Intestinal Bacterial Flora}

Hayato Tokumoto $^{1 *}$, Toshiyuki Nomura ${ }^{1}$, Hideyuki Hoshi $^{2}$, Yasutaka Nii ${ }^{1}$, Toshiharu Ootani ${ }^{1}$ and Kenta Nomoto ${ }^{1}$

\author{
Received 7 October 2016; Accepted 18 November 2016
}

\begin{abstract}
Particles of additives that are ingested along with food can either adhere to the intestinal microflora or be absorbed, and these may possibly lead to illnesses caused by changes in the microflora composition. Barely $1 \%$ of $\mathrm{Fe}_{2} \mathrm{O}_{3}$ particles dissolve in acids present in the stomach. In addition, the direct administration of $\mathrm{Fe}_{2} \mathrm{O}_{3}$ particles into the stomach with a probe showed no adverse health effects. However, mixing $\mathrm{Fe}_{2} \mathrm{O}_{3}$ particles of a smaller diameter into food and orally administering the dose over a period of more than 2 weeks encouraged the multiplication of the diarrhea-causing Clostridium family amongst intestinal flora, indicating the cause of the diarrhea outbreak. On the other hand, multiplication of the Clostridium species was suppressed by the multiplication of another family within the intestinal flora, namely Lactobacillus. It was confirmed that by analyzing the formation of fermentation products such as hydrogen, acetic acid, and lactic acid, symptoms of diarrhea caused by the alteration of intestinal microflora composition spontaneously recovered.
\end{abstract}

Keywords: $\mathrm{Fe}_{2} \mathrm{O}_{3}$ particle, Intestinal microflora, Clostridium, Lactobacillus.

\section{1. 緒言}

金属ナノ粒子は食品業界では包装材料や着色料, 製造 助剂として広く利用されている。実際に，酸化第二鉄が 赤色の着色料, 二酸化チタンが白色の着色料や包装材料, 二酸化ケイ素が粉末の物性改良などに使用されている。 ナノ粒子はバルクと比べて, 比表面積の大きさや反応性 の高さ, 磁性や導電性, 光学特性に優れていることから 注目を集めている $[1]$ 。その結果, ナノ粒子を使用した商 品の増加によって, 日常生活中で無意識的にナノ粒子を 摂取する頻度が高まり[2], ナノ粒子の生体への毒性が懸 念されている[3]。

工業分野でナノというと 1 〜 $100 \mathrm{~nm}$ の範囲のことを指 すが，食品分野におけるナノの範囲はまだ明確に決まっ ていない。その理由としては, 食品では数 $10 \mu \mathrm{m}$ のス ケールで食感や加工特性に大きな変化を与えるとされて おり, 農林水産省委託研究プロジェクト「食品素材のナ

1 大阪府立大学 大学院工学研究科 物質 $\cdot$ 化学系専攻 （） 599-8531 大阪府堺市中区学園町 1-1）

Department of Chemical Engineering, Osaka Prefecture University

(1-1 Gakuen-cho, Naka-ku, Sakai, Osaka 599-8531, Japan)

2 大阪府立大学大学院人間社会システム研究科 現代システム科学 専攻

（ T59-8531 大阪府堺市中区学園町 1-1）

Graduate School of Humanities and Sustainable System Sciences, Osaka Prefecture University

(1-1 Gakuen-cho, Naka-ku, Sakai, Osaka 599-8531, Japan)

* Corresponding Author tokumoto@chemeng.osakafu-u.ac.jp
ノスケール加工および評価技術の開発」では粒子径が $10 \mathrm{~nm} \sim 100 \mu \mathrm{m}$ の範囲を対象として研究が行われてき た。特に, 食品添加物粒子は食品とともに大量に摂取さ れる可能性があり, 健康への影響を検討する必要がある と考えられる。

現在, 食品添加物粒子が腸管壁に付着し炎症を起こす こと[4]や, 粒子が細菌に及ぼす影響[5]について報告され ている。銀ナノ粒子のラット経口投与では, 胃, 肝臓, 腎臓, 肺などのほか, 脳にも少量のナノ粒子が蓄積して いたとの報告がある[6]。別のマウス経口投与試験では, 肝蔵, 脾蔵, 腎臓に体内に吸収されたナノ粒子が分布す る[7]という結果も得られている。酸化亜鉛ナノ粒子のマ ウス経口投与試験では, 骨, 腎藏, 膵臓に蓄積していた [8]との報告もある。銅ナノ粒子のマウス経口投与試験で は, 肝臓, 腎臓, 血液中に蓄積が多いことが知られてい る[9]。食品とともに添加物の粒子が体内に取り込まれ, 腸内細菌叢に付着または, 吸収される可能性は容易に想 定できる。しかしながら, 生体への毒性については, ナ ノ粒子の体内での蓄積や分布を調べたものが多く, 腸内 細菌叢に与える影響については, ほとんど報告がなされ ていない。

ヒトの腸内には約 100 兆個もの腸内細菌が生息してい ると言われる。ヒトの胎児は出生時に腸内細菌をもって いないとされるが, 出生時に母親から腸内細菌を受け継 ぎ，乳児期に腸内細菌が腸管内に定着することが知られ ている。その後は食物, 免疫, 環境などの影響を受けな 
がら, 徐々に腸内細菌叢が形成される。一般に, 経口摂 取された食物は胃から大腸までの消化管を介して，約 3 日間程度で消化吸収され, 排泄される。口腔内では唾液, 胃では胃酸により食物は分解されるが, 強酸性の胃酸に より, 食物中に含まれる多くの微生物は胃内で殺菌され, 生息する微生物はわずかである。その後，十二指腸，小 腸を経る中で，膵液，胆汁，腸液の分泌を受けながら消 化が進み，アルカリ性に中和される。このとき，腸内細 菌は小腸から大腸にかけ，その数を増加させるが，嫌気 性環境下である大腸内が主な生息場所で，内容物 $1 \mathrm{~g}$ 当 たり $10^{10} \sim 10^{11}$ 個の微生物を含むとされており，この内 容物（臯）には微生物が重量比で約 6 割含まれることが 知られている[10]。

そこで本研究では, 食品添加物ナノ粒子が腸内細菌丵 へ与える影響を解析するために，ナノ粒子をマウスへ経 口投与し, 排出された資に含まれる腸内細菌の菌叢構造, 構成菌種の変動について, 腸内細菌叢（糞）を試験管内 で培養し，その発酵挙動から，ナノ粒子が腸内細菌叢に 与える影響を解析した。

\section{2. 実験方法}

\section{1 使用した食品添加物用 $\mathrm{Fe}_{2} \mathrm{O}_{3}$ 粒子}

本研究では, 高純度化学研究所から購入した公称径 0.3, $1.0 \mu \mathrm{m}$ の乾燥状態にある $\mathrm{Fe}_{2} \mathrm{O}_{3}$ 粒子を実験に用い た。分散液として使用する場合は, 純水や生理食塩水を 分散媒とし, $\mathrm{Fe}_{2} \mathrm{O}_{3}$ 粒子を任意の濃度となるよう超音波 洗浄機で 15 分間分散させて実験に用いた。 $\mathrm{Fe}_{2} \mathrm{O}_{3} \mathrm{NPs}$ 分 散液中の粒子のメジアン径 $\mathrm{D}_{\mathrm{P} 50}$ は, ゼー夕電位・粒子径 測定システム ELS-Z（大塚電子）を用いて測定した。

\section{2 実験動物}

実験動物の飼育，管理は，大阪府立大学が定める施設 動物実験規則を遵守し, 動物実験は, 動物実験委員会に よる審査を経て実施した。日本 ILCより購入したマウス （2３ 週齢） 20 匹を 1 ゲージ当たり 4 匹で，投与するナ ノ粒子の粒子径と投与量の違う合計 5 ゲージに分けて, 大阪府立大学 $\mathrm{C} 11$ 棟（動物育成棟）で飼育した。飼育中 のマウスの健康状態は, ゲージごとのマウスの平均体重 の経時変化と, 腸内細菌叢の構造変化を指標にした。実 験にはマウスの粪を腸内細菌叢として採取して用いた。 ゲージごとのマウスの初期平均体重に有意な差はない。

\section{3 経口投与針（ゾンデ）による経口投与}

滅菌した $0.9 \%$ 生理食塩水に, 1 回の投与で, $\mathrm{Fe}_{2} \mathrm{O}_{3}$ 粒 子の投与量が $1.6,8.0 \mathrm{mg}$ となるように調整したナノ粒 子分散液 $400 \mu \mathrm{L}$ を,ゾンデにより投与した。このときの ゲージごとの経口投与の条件を, Table 1 に示した。対照 （ゲージ番号 1）では，生理食塩水 $400 \mu \mathrm{L}$ をゾンデによ り経口投与した[11]。経口投与は週に 1 回, 合計で 4 回 行った。ゾンデによる経口投与は，28 日間の実験期間内 で, この 4 回だけである。

\section{$2.4 \mathrm{Fe}_{2} \mathrm{O}_{3}$ 粒子を混練した餌を給餌する経口投与}

マウス粉末飼料と $\mathrm{Fe}_{2} \mathrm{O}_{3}$ 粒子を混合し, 純水を粉末飼 料と同量加え, 15 分間混錬を行った。その後, ペレット
Table 1 Oral administration condition by the sonde for mouse

\begin{tabular}{ccc}
\hline cage number & nominal dinameter $[\mu \mathrm{m}]$ & dose $[\mathrm{mg}]$ \\
\hline 1 & - & - \\
2 & 0.3 & 1.6 \\
3 & 0.3 & 8.0 \\
4 & 1.0 & 1.6 \\
5 & 1.0 & 8.0 \\
\hline
\end{tabular}

Table 2 The content of the $\mathrm{Fe}_{2} \mathrm{O}_{3}$ NPs in the feed for mouse

\begin{tabular}{ccc}
\hline cage number & nominal dinameter $[\mu \mathrm{m}]$ & content $[\%]$ \\
\hline 1 & - & - \\
2 & 1 & 0.007 \\
3 & 1 & 0.07 \\
4 & 0.3 & 0.014 \\
5 & 0.3 & 0.14 \\
\hline
\end{tabular}

Table $3 \mathrm{D}_{\mathrm{p} 50}$ of $\mathrm{Fe}_{2} \mathrm{O}_{3} \mathrm{NPs}$ in culture medium

\begin{tabular}{ccc}
\hline nominal dinameter $[\mu \mathrm{m}]$ & $\mathrm{pH}[-]$ & $\mathrm{D}_{\mathrm{p} 50}[\mathrm{~nm}]$ \\
\hline 0.3 & 7.6 & 109.3 \\
1.0 & 7.5 & 139.7 \\
\hline
\end{tabular}

状に成形して $100^{\circ} \mathrm{C} て ゙$ 乾燥させた。予備実験により, $\mathrm{Fe}_{2} \mathrm{O}_{3}$ 粒子を $1.6 \mathrm{mg}$ 投与すると, 粒子径 $0.3 \mu \mathrm{m}$ では約 $20 \%$, 粒子径 $1.0 \mu \mathrm{m}$ では約 10\%の粒子が腸内細菌叢とと もに排出したことから，これをマウスが 1 日で排出可能 な粒子量と定義した。また，マウスの1日の接餌量を測 定し, マウス飼料への $\mathrm{Fe}_{2} \mathrm{O}_{3}$ 粒子の含有率を決定した (Table 2)。この実験では，粒子は毎日マウスに摂取され る。

\section{5 対照のマウス群から採取した腸内細菌叢への $\mathrm{Fe}_{2} \mathrm{O}_{3}$ 粒子の暴露実験}

純水にスキムミルク粉末を $10 \mathrm{~g} / \mathrm{L}$ となるように投与 し, 液体培地を作製した。培養器には, 内容積 $21 \mathrm{~mL}$ の オートサンプラーバイアルを用いた。総液量を $5 \mathrm{~mL}$ と し，作製した液体培地 $2.5 \mathrm{~mL}$ に，2.1 で作成した $\mathrm{Fe}_{2} \mathrm{O}_{3}$ 粒子の分散液 $2.5 \mathrm{~mL}$ を最終槽内濃度で $50 \mathrm{mg} / \mathrm{L}$, 対照の マウスから採取した腸内細菌叢を $40 \mathrm{mg}$ となるように混 合した。対照は分散液の代わりに純水を混合した。 $\mathrm{Fe}_{2} \mathrm{O}_{3}$ 粒子の分散液中の粒子の粒子径を Table 3 に示した。バ イアル瓶をブチルゴム栓とアルミシールで密閉した後, ガス置換装置（三紳工業社製，IP-8）を用いてへッドス ペースを窒素ガスで置換し，1.2気圧とした。ガス置換に より嫌気状態としたバイアル瓶を卯卵器に静置し, $310 \mathrm{~K}$ で腸内細菌叢の培養を行った。

\section{6 ナノ粒子を経口投与して採取した腸内細菌叢の培 養実験}

純水にスキムミルク粉末を $10 \mathrm{~g} / \mathrm{L}$ となるように投与 し，基質溶液を作製した。次にオートサンプラーバイア

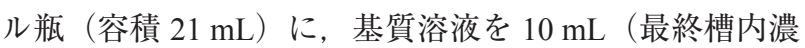
度 $10 \mathrm{~g} / \mathrm{L})$, マウスの腸内細菌叢 $250 \mathrm{mg}$ を投入後, ゴム 栓で密封した。対照は粒子を経口投与していないマウス の腸内細菌叢を同じ基質溶液中に投入した。ガス置換装 
置を用いて, ヘッドスペースを窒素ガスで置換し, 1.2 気 圧とした。ガス置換により嫌気状態としたバイアル瓶を 孵卵器に静置し, $310 \mathrm{~K}$ で腸内細菌叢の培養を行った。

\section{7 気相分析}

バイアル瓶のヘッドスペースからガスタイトシリンジ で $0.5 \mathrm{~mL}$ の気相成分を採取し, ガスクロマトグラフィー （Shimadzu GC-8APT）で発酵ガスの組成を分析した。カ ラムは $3 \mathrm{~m} \times 3.0 \mathrm{~mm}$ のステンレスカラムに充填した Prapak Q（日本ウォーターズ株式会社）を用いた。キャリアガ スにはアルゴンガスを使用し, 流速は $20 \mathrm{~mL} / \mathrm{min}$ とした。 インジェクターとカラムオーブン, 検出器の温度はそれ ぞれ 373 と $343 ， 373 \mathrm{~K}$ に設定した。標準ガス（STD）と して $80 \%$ の窒素と $20 \%$ の二酸化炭素からなる混合ガス と， 100\%のメタンガス，100\%の水素ガスを使用した。 データは 3 つの独立した培養器から測定し, 平均值と標 準䛊差を算出した。

\section{8 有機酸濃度}

腸内細菌叢を培養後, 液相中の有機酸組成を分析した。 液相成分は注射器で嫌気状態を維持したままバイアルか ら $0.5 \mathrm{~mL}$ 採取し, $15000 \mathrm{rpm}$ で 5 分間遠心分離し, 上済 み液をフィルター濾過して高速液体クロマトグラフィー に供した。

また，腸内細菌叢んに含まれる有機酸量を測定するた めに，腸内細菌叢を純水 $10 \mathrm{~mL}$ 中に投入し，Voltex で十 分擋拌した後, $0.5 \mathrm{~mL}$ を採取し $15000 \mathrm{rpm}$ で 5 分間遠心 分離した。上澄み液をフィルター滤過後, 高速液体クロ マトグラフィーに供した。

有機酸濃度の測定は, 高速液体クロマトグラフィー（日 本分光株式会社 LC-2000Plus）で測定した。カラムはガー ドカラムに RSpak KC-G（昭和電工株式会社）, 主カラム にRSpak KC-811（昭和電工株式会社）を2本連結して用 い, カラムオーブンの温度は $333 \mathrm{~K}$ とした。移動相とし て $3 \mathrm{mM}$ 過塩素酸水溶液を使用し, 流速は $0.8 \mathrm{~mL} / \mathrm{min}$ と した。カラム通過後, 反応液と反応させて呈色させ, 吸 光度を測定した。反応液は $0.2 \mathrm{mM} \mathrm{BTB}, 15 \mathrm{mM}$ リン酸 水素二ナトリウムの水溶液を用い, 流速は $1.2 \mathrm{~mL} / \mathrm{min}$ と した。標準試料として，代表的な有機酸を 1，5，10， $50 \mathrm{mM}$ となるように調製した水溶液を用いた。培養液中 の有機酸の濃度は, ChromNAV（日本分光株式会社）で 算出した。

\section{3. 実験結果および考察}

\section{1 ゾンデによる粒子の経口投与}

ゾンデによる 32 日間の経口投与実験期間中に, $\mathrm{Fe}_{2} \mathrm{O}_{3}$ 粒子を 1 週間から 10 日に 1 回, 合計 4 回（投与日； 1 , 11，18，25日目）投与したときの，ゲージごとのマウス の平均体重変化を Fig. 1 に示す。腸内細菌叢の構造変化 が要因となる主な疾病は下痢であるが，毒素を生成する 菌が菌叢内で優勢化することに起因する[12]。一般に, 下痢を発症すれば脱水症状を併発するので，体重変化を 健康状態の指標とした。4 回目の投与終了後, 1 週間が過 ぎても，各ゲージのマウスの体重に大きな変化は見られ

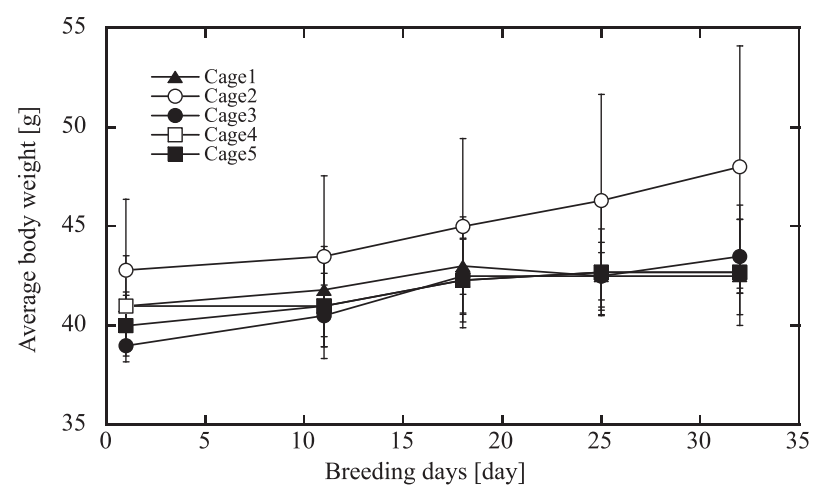

Fig. 1 Change of the average body weight of mouse during oral administration by sonde

cage1 (ム) cage2 $(\bigcirc) \quad$ cage3 $(\bigcirc) \quad$ cage4 $(\square) \quad$ cage5

Data are means $\pm \mathrm{SE}$ of results from four independent samples.

なかった。用いた $\mathrm{Fe}_{2} \mathrm{O}_{3}$ 粒子は, 本来, 食品添加物とし て安全性が確認されているものであり, 投与間隔の空い た経口摂取による生体への影響は, 体重変化を見る限り, ほとんどないと考えられる。

\section{2 粒子を混練した餌の連続経口投与}

2 種類の粒子径と投与量で粒子を経口投与して飼育し たマウスの体重変化を Fig. 2 に示す。その結果, ゲージ 5 の粒子径 $0.3 \mu \mathrm{m}$ の $\mathrm{Fe}_{2} \mathrm{O}_{3}$ ナノ粒子を慨への混練濃度 $0.14 \%$ で投与した条件において, 飼育日数 12 日目から 14 日目にかけて体重が約 10\%以上も減少した。さらに, 腸 内細菌叢の含水率が増加していたことから（Table 4), このゲージ内の全てのマウスが下痢を発症したと認定し た。また，下痢によって体内の水分と摂慨した慨を一時 的に大量に排出したため, 体重が急激に減少したのでは ないかと考えられる。また, この体重変化は一過的なも ので, 数日後には腸内細菌叢の含水率も, 体重もほぼ発 症前の状態に戻っていた。一般に, 下痢は腸からの分泌 物が増えることや, 腸内に流入した物質が水分を引き寄 せ，腸管内の浸透圧が上がって下痢になることが知られ ている。下痢の原因菌は腸内に常在する腐敗菌群である が, 多くは Clostridium 属で, 腸内細菌叢でこの腐敗菌 群が優勢化すると, 毒素を生成し, この毒素を洗浄する ために，腸内に大量に水が分泌される[13]。また，腸内 に常在菌として存在する乳酸菌群が, この腐敗菌群の増 殖を抑制するために, 腸内で増殖を始め, その結果症状 が改善される[13]。

以上の結果から, この腐敗菌群と乳酸菌群の発酵挙動 を捉えれば, 腸内細菌叢の状態を把握することができる。

\section{3 粒子を経口投与していないマウスの腸内細菌叢に} 粒子を暴露した菌叢中の微生物の培養実験

粒子を含まない通常の慨で飼育した腸内細菌叢を採取 し, これに粒子を直接暴露し, 培養を行った時の腸内細 菌叢中の微生物が生産する水素生成量を Fig. 3 に示す。 培養 7 日目の水素生成量は, 対照で $1.44 \mathrm{~mL}$ となった。 一方, 粒子径 $0.3 \mu \mathrm{m}$ の $\mathrm{Fe}_{2} \mathrm{O}_{3}$ 粒子を暴露した場合の生成 量は $1.36 \mathrm{~mL}$ であった。また, 粒子径 $1.0 \mu \mathrm{m}$ の $\mathrm{Fe}_{2} \mathrm{O}_{3}$ 粒 


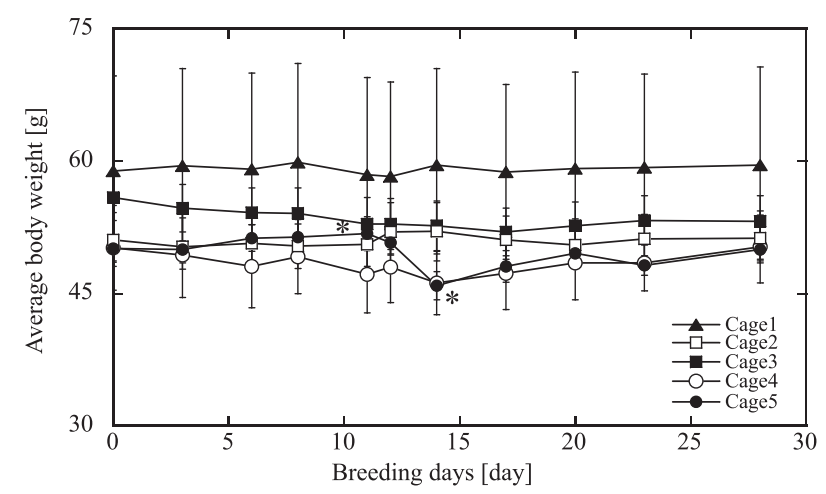

Fig. 2 Change of the average body weight of mouse during oral administration

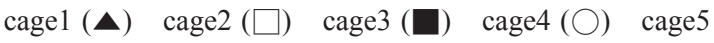

Data are means $\pm \mathrm{SE}$ of results from four independent samples.

*: Significant difference of average body weight for 11-14 breeding days at $P<0.05$

Table 4 Moisture content of the feces

\begin{tabular}{cc}
\hline & moisture content $[\%]$ \\
\hline before diarrhea & 23.3 \\
diarrhea & 40.8 \\
after healing & 32.7 \\
\hline
\end{tabular}

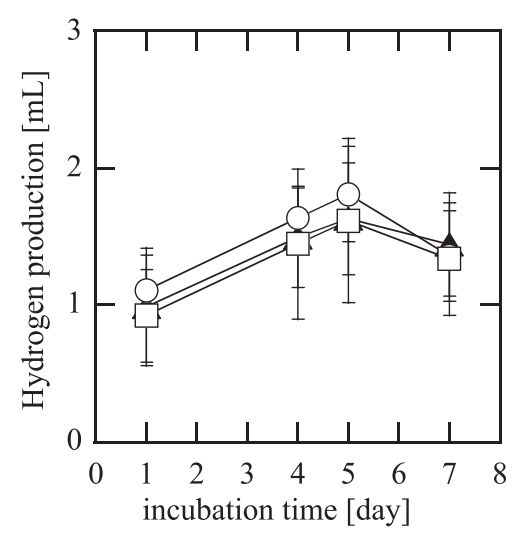

Fig. 3 Hydrogen production from feces culture when the nanoparticles were exposured to the intestinal bacteria

Control ( $\Delta$ ) particle size $0.3 \mu \mathrm{m}(\bigcirc)$ particle size1.0 $\mu \mathrm{m}(\square)$

Data are means $\pm \mathrm{SE}$ of results from three independent samples.

子を投与した場合では, $1.34 \mathrm{~mL}$ であり, 粒子の暴露に よる水素生成量の変化はないと考元られる。腸内細菌丵 と類似の菌叢である土壤菌叢に粒子径が約 $10 \mathrm{~nm}$ の $\mathrm{Fe}_{2} \mathrm{O}_{3}$ ナノ粒子を暴露した場合では, 菌叢構造が変化す ることが報告されている[5]。本実験で用いた腸内細菌叢 は団塊の形状であり, そのため, $\mathrm{Fe}_{2} \mathrm{O}_{3}$ 粒子を暴露して も, 塊状の腸内細菌叢の表面近傍の微生物としか粒子が 接触できず，このことが原因で，水素の生成量に変化が 見られなかったのではないかと推察される。

\section{4 ゾンデによる経口投与後に採取した腸内細菌叢の 培養実験}

Fig. 4 に,ゾンデによる経口投与の 1 日後に採取した
腸内細菌叢を、スキムミルクを基質として培養した時の， 菌叢中の微生物が生産する水素生成量を示す。Clostridium 属は下痢の原因菌で, 発醅代謝産物として, 水素を生成 することがよく知られている[14]。そこで, 水素生成量 を測定したところ, 培養終了時 (7 日後) の最終水素生 成量が対照では $5.59 \mathrm{~mL}$ となった。一方, 粒子径 $0.3 \mu \mathrm{m}$ の $\mathrm{Fe}_{2} \mathrm{O}_{3}$ 粒子を $1.6 \mathrm{mg}$ または, $8.0 \mathrm{mg}$ で投与した場合で は $1.14 \mathrm{~mL}$ と $2.41 \mathrm{~mL}$ となり, 対照と比較すると, 最終 水素生成量が減少した。粒子径 $1.0 \mu \mathrm{m}$ を投与した場合で は, 培養初期にばらつきがあるものの, 最終生成量は $1.6 \mathrm{mg}, 8.0 \mathrm{mg}$ で投与した場合に, それぞれに対して水 素発生量が $4.29 \mathrm{~mL}$ と $2.89 \mathrm{~mL}$ となり, 対照と比べて生 成量は減少していた。ばらつきの原因であるが，この害 験方法はゾンデを用いているため, 排出される腸内細菌 叢はどうしても粒子含有量が均一になりにくく, 微生物 塊の局在があり, 培養初期にはその影響が出たと考えら れる。以上の結果から, 粒子径がより小さいほうが, 水 素生成量の変化が大きいのではないかと考えられる。

\section{5 ナノ粒子を混練した慨を給慨して採取した腸内細 菌叢の培養実験}

ゼブラフィッシュにナノ粒子 $\left(\mathrm{CuSO}_{4}\right)$ を混鍊した餌 を与えると, その腸内細菌叢の構造が変化することが報 告されている[15]。そこで, ナノ粒子を混練した慨を給 慨して採取した腸内細菌叢の培養実験を行った。腸内細 菌叢は, 経口投与を開始してから, 15 日目に排出された ものを採取して培養した。このときの水素生成量の経時 変化を Fig. 5 に示す。対照と比較して, 培養 7 日後の水 素生成量は, 対照では $0.76 \mathrm{~mL}$, 粒子径 $0.3 \mu \mathrm{m}$ の $\mathrm{Fe}_{2} \mathrm{O}_{3}$ 粒子を含有率 $0.014 ， 0.14 \%$ で投与した条件では， 2.59 , $7.46 \mathrm{~mL}$ 生成し, 粒子径 $1.0 \mu \mathrm{m}$ の $\mathrm{Fe}_{2} \mathrm{O}_{3}$ 粒子を含有率 $0.007,0.07 \%$ で投与した条件では, $2.18,7.87 \mathrm{~mL}$ 生成し た。この結果より, $\mathrm{Fe}_{2} \mathrm{O}_{3}$ 粒子の投与量が多いほど, 水 素生成量が増加することが分かった。このとき, 粒子径 $0.3 \mu \mathrm{m}$ の $\mathrm{Fe}_{2} \mathrm{O}_{3}$ 粒子を含有率 $0.14 \%$ で投与した条件にお いて，全てのマウスが下痢を発症していた（Fig. 2)。下 㾥を発症した条件の腸内細菌叢から生成する水素生成量 は, 対照と比較して劇的に増加した。嫌気発酵の中間段 階である酸生成過程では下痢の原因菌であるClostridium 属が水素を生成する。菌丵中の微生物による水素生成量 が変化すると, 菌叢構造も呼応して変化が起こることが 報告されている[16]ことから, 下痢の原因菌が特異的に 増殖しているのではないかと推察される。

\section{6 体重変化の前後の腸内細菌叢が生成する有機酸}

Table 2 で体重が大きく減少した 15 日目と, その前後 （4 日目と 26 日目）の腸内細菌叢を採取して培養した時 の, 液相中の有機酸濃度を分析した結果を Fig. 6 に示す。 一般に, 酢酸は Clostridiaceae, 乳酸は Lactobacillaceae の微生物の代謝産物である[17]。図より, 下痢時の乳酸 生成量は, 下痢前と比較して増加した。これは, Clostridiaceae が優勢化している菌丵では, Lactobacillaceae の乳酸生成が促進されたからであると考 えられる。また, 下痢を発症する前と比較して, 治癒し 


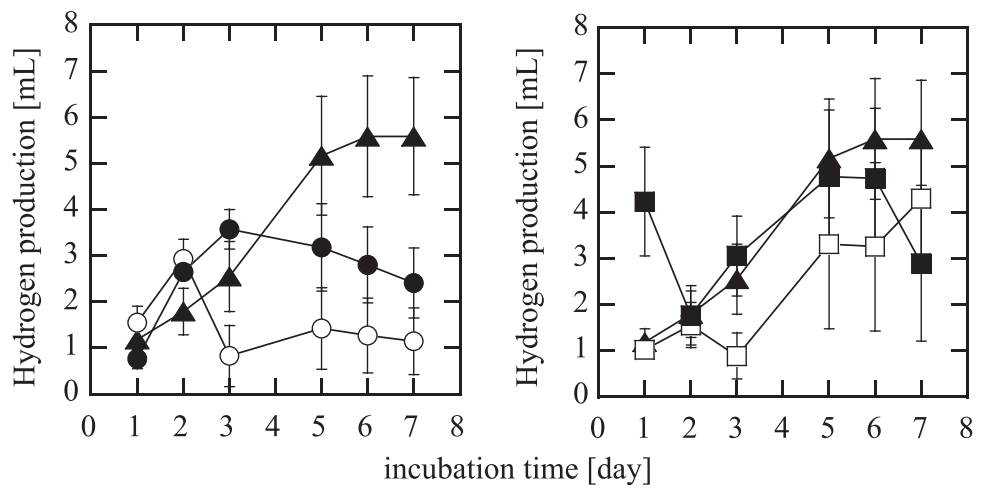

Fig. 4 Hydrogen production from feces culture

Feces was collected after 1 day oral administration.

Control $(\boldsymbol{\Delta}) \quad$ particle size $0.3 \mu \mathrm{m} 1.6 \mathrm{mg}(\bigcirc) \quad$ particle size $0.3 \mu \mathrm{m} 8.0 \mathrm{mg}(\bigcirc) \quad$ particle size $1.0 \mu \mathrm{m} 1.6 \mathrm{mg}(\square) \quad$ particle size $1.0 \mu \mathrm{m} 8.0 \mathrm{mg}$

Data are means $\pm \mathrm{SE}$ of results from three independent samples.

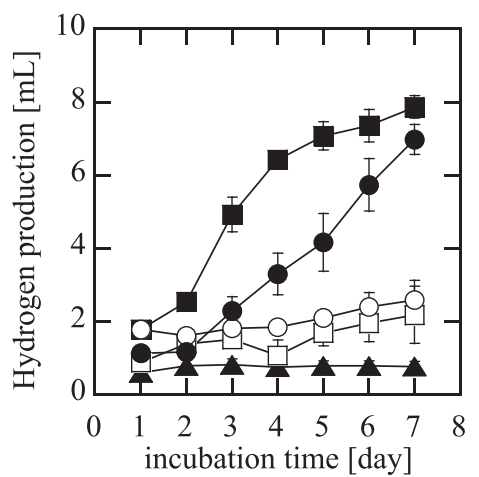

Fig. 5 Hydrogen production with incubation time from feces culture

Feces was collected after 15 days oral administration.

Control ( $\Delta$ ) particle size $1.0 \mu \mathrm{m} 0.007 \%(\bigcirc)$ particle size $1.0 \mu \mathrm{m} \quad 0.07 \%$ (○) particle size $0.3 \mu \mathrm{m} \quad 0.014 \%$ ( $\square$ ) particle size $0.3 \mu \mathrm{m} 0.14 \%$ (

Data are means $\pm \mathrm{SE}$ of results from three independent samples.

た後の酢酸生成量は約 $60 \%$ 減少した。これは, Lactobacillaceae が優勢化した菌叢では Clostridiaceaeな どの酢酸生成菌の代謝が抑制されたのではないかと考え られる。以上より, Clostridiaceae が菌叢内で優勢化に 伴って, Lactobacillaceae が優勢化した結果, 乳酸の生成 が促進され，酢酸生成菌の代謝が抑制されたのではない かと考えられる。

\section{4. 結 言}

(1) 腸内細菌叢に $\mathrm{Fe}_{2} \mathrm{O}_{3}$ ナノ粒子を暴露しても菌叢構造 の変化は，ほとんど見られないことが発酵挙動の解 析から明らかとなった。

(2) ゾンデ（経口投与針）を用いて，胃に直接 $\mathrm{Fe}_{2} \mathrm{O}_{3}$ ナ ノ粒子を投与しても腸内細菌叢の構造変化は起こら ず，投与した粒子は 1〜2 日間で体外に排出された。

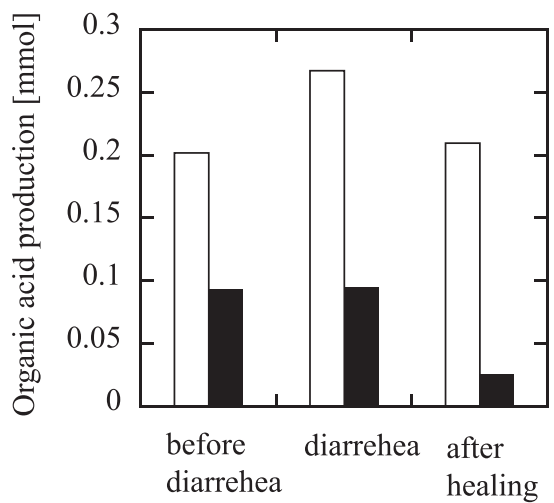

Fig. 6 Organic acid production from feces culture for $24 \mathrm{~h}$ (lactic acid ( $\square$ ), Acetic acid ( $\square$ ))

Three independent samples were combined for analyzing organic acid.

(3) 餌に粒子径の小さな $\mathrm{Fe}_{2} \mathrm{O}_{3}$ ナノ粒子を混合して経口 投与すると, 約 2 週間後に下痢を発症し, 数日内で その症状は自然治癒したことから, 微生物がナノ粒 子を取り込み, 急激な毒性を受けるのではなく, 長 期的な接触により, 一部の微生物種が毒性を受け, 一旦，菌叢構造が変化するが，この変化を修復する 微生物種により, 徐々に元の菌叢構造に戻ることが 示された。

（4）下痢を発症した腸内細菌叢中では，下痢の原因菌で あるClostridium 属の増殖による酢酸生成が顕著で, 引き続いて，この症状を抑制する Lactobacillus 属の 増殖による乳酸の生成が起こることが明らかとなっ た。

[謝辞] 本研究の一部は, 科学研究費補助金（No. 26560066）および 2014 年度粉体工学情報センターの研究 助成を受け行われた。ここに感謝の意を表す。

\section{References}

[1] S. T. Joyce, D. M. Andrew, C. H. Paul, T. J. John, Research strategies for safety evaluation of nanomaterials: Risk assessment of nanoparticles, Toxicological Sciences, Japan, 89 (2005) 42-50. 
[2] B. Nowack, Thomas D. Bucheli, Occurrence, behavior and effects of nanoparticles in the environment, Environmental Pollution, Netherlands, 150 (2007) 5-22.

[3] G. Oberdorster, E. Oberdörster, J. Oberdörster, Nanotoxicology: an emerging discipline evolving from studies of ultrafine particles, Environ Health Perspect., America, 113 (2005) 823-839.

[4] J. J. Powell, R. S. J. Harvey, P. Ashwood, R. Wolstencroft, M. E. Gershwin, R. P. H. Thompson, Immune potentiation of ultrafine dietary particles in normal subjects and patients with inflammatory bowel disease, Journal of Autoimmunity, Netherlands, 14 (2000) 99-105.

[5] S. He, Y. Feng, N. Gu, Y. Zhang, X. Lin, The effect of $\gamma-$ $\mathrm{Fe}_{2} \mathrm{O}_{3}$ nanoparticles on Escherichia coli genome, Environmental Pollution, Netherlands, 159 (2011) 34683473.

[6] Y. S. Kim, J. S. Kim, H. S. Cho, D. S. Rha, J. M. Kim, J. D. Park, B. S. Choi, R. Lim, H. K. Chang, Y. H. Chung, I. H. Kwon, J. Jeong B. S. Han, I. J. Yu, Twenty-eight-day oral toxicity, genotoxicity, and gender-related tissue distribution of silver nanoparticles in Sprague-Dawley rats, Inhal Toxicol., America, 20 (2008) 575-583.

[7] J. Wang, G. Zhou, C. Chen, H. Yu, T. Wang, Y. Ma, G. Jia, Y. Gao, B. Li, J. Sun, Y. Li, F. Jiao, Y. Zhao, Z. Chai, Acute toxicity and biodistribution of different sized titanium dioxide particles in mice after oral administration, Toxicol Lett., Netherlands, 168 (2007) 176-185.

[8] B. Wang, W. Y. Feng, M. Wang, T. C. Wang, Y. Q. Gu, M. T. Zhu, H. Ouyang, J. W. Shi, F. Zshang, Y. L. Zhao, Z. F. Chai, H. F. Wang, J. Wang, Acute toxicological impact of nanoand submicro-scaled zinc oxide poweder on healthy adult mice, Jornal of Nanoparticle Research, Germany, 10 (2008) 176-185.

[9] Z. Chen, H. Meng, H. Yuan, G. Xing, C. Chen, F. Zhao, Y.
Wang, C. Zhang, Y. Zhao, Identification of target organs of copper nanoparticles with ICP-MS technique, J. Radioanalytical Nuclear Chem., Germany, 272 (2007) 599603.

[10] A. M. Stephen, J. H. Cummings, The microbial contribution to human faecal mass, J Med Microbiol., UK, 13 (1980) 4556.

[11] K. Diehl, R. Hull, D. Morton, R. Pfister, Y. Rahemampianina, D. Smith, J. Vidal, C. Volstenbosch, A good practice guide to the administration of substances and removal of blood, including route and volumes, J Applied Toxicology, 21 (2001) 15-23.

[12] D. E. Voth, J. D. Ballard, Clostridium difficile toxins: mechanism of action and role in disease, Clin Microbiol Rev, America, 18 (2005) 247-263.

[13] T. Mituoka, Prebiotics and Intestinal Flora, Journal of Intestinal Microbiology, 16 (2002) 1-10.

[14] S. Supaphol, S. N. Jenkins, P. Intomo, I. S. Waite, A. G. O'Donnell, Microbial community dynamics in mesophilic anaerobic co-digestion of mixed waste, Bioresource Technology, Netherlands, 102 (2011) 4021-4027.

[15] D. L. Merrifield, B. J. Shaw, G. M. Hrper, I. P. Soaud, S. J. Davies, R. D. Handy, T. B. Henry, Ingestion of metalnanoparticle contaminated food disrupts endogenous microbiota in zebrafish., Environmental Pollution, Netherlands, 174 (2013) 157-163.

[16] T. Laothanachareon, S. Kanchanasuta, W. Mhuanthong, C. Phalakornkule, N. Pisutpaisal, V. Champreda, Analysis of microbial community adaptation in mesophilic hydrogen fermentation from food waste by tagged 16S rRNA gene pyrosequencing, Journal of Environmental Manegement, Netherlands, 144 (2014) 143-151.

[17] A. Watabe, Carbohydrate fermentation in the colon, Journal of Intestinal Microbiology, 19 (2005) 169-177. 